\title{
THE INFLUENCE OF EMPLOYEE EMPOWERMENT, SOFT SKILLS AND HARD SKILLS TOWARDS EMPLOYEE PERFORMANCE IN HOTEL/ HOSPITALITY INDUSTRY
}

\author{
Anthonius \\ Universitas Kristen Maranatha \\ Email: anthony_partners@yahoo.com
}

\begin{abstract}
The growth and competition of Indonesia's hotel industry, especially during the Covid-19 pandemic, has hardly pushed them to maintain their corporate and employee performance. The factors related to human resource and hospitality industry, which cloud significantly affects the employee's performance are employee empowerment, soft skill and hard skill. This research is a quantitative research with hypothesis test. The samples used are 100 active employees of 4 stared rated hotels. This research uses questionnaire as the research instrument and the data analysis conducted by applying Structural Equation Modeling (covariances based SEM). This research contributes to Indonesia's hotel industry by stating that while the employee empowerment factor has no impact toward the employee performance, both the hard and soft skill factors are positively impacting the employee's performance in Indonesia' hotel industry.
\end{abstract}

Keywords: employee empowerment, hard skill, soft skill, employee performance, Indonesia

\section{INTRODUCTION}

The competition between ASEAN countries including Indonesia has becoming fiercer than ever (Plummer, Petri, \& Zhai, 2014), this include the competition in both hotel and tourism industries. In Indonesia, 4 and 5 star rated hotel industry seen significant growth for the past couple of years. The ongoing Covid-19 pandemic has forced the corporations to struggle in effort to survive and remain competitive. One major aspect that would determine the success of a company/ organization is superior human resource with good performance (Singh, Hu \& Roehl, 2007; Sonnentag, 2000). The great human resource in a company has becoming an important asset in the hospitality industry, thus it is very important to manage both the employee's skills and knowledge to build the long term superior competitiveness of a company (Lytras, 2008). This statement inline with as study which states that human resource contributes to the company's competitiveness, enhancing productivity and increasing profitability (Gull et al., 2012; Saleem \& Amin, 2013).

Human resource has becoming the most important aspect of hotel industry in the evolving 4.0 era, as it is a determining factor that affects the quality of service delivery. The employee's performance, in relation to the human resource quality, believed to be a factor that require attention and carefully managed in the hotel industry (Pragiwani et al., 2018), especially the employees that directly dealing with the customers, as it affects costumer's satisfaction and perception toward the provided service (Hartline \& Ferrell, 1996).

The efforts taken to improve the performance of an employee have always been an interesting issue to discuss. There are lots of factors and researches that affecting an employee's performance. The 
interesting factors to look at in hospitality industry are employee empowerment and skills as those variables are closely linked to human resource quality and behavior within a company especially in the hotel industry.

In conjunction to the ongoing pandemic situation and the requisition of hotel industry in order to survive during these time, employee performance has become one of the most observed factor. The purpose of this research is to test whether the employee empowerment, hard and soft skills are affecting the employee's performance in Indonesia's hotel industry.

\section{LITERATURE REVIEW AND HIPOTHESYS DEVELOPMENT}

\section{Employee Empowerment}

Employee empowerment is more suitable to be implemented in a highly competitive business environment that have decentralized organization structure whereas the authority distribution doesn't lie on just one division, one of them is the hotel industry (Meyerson \& Dewettinck, 2012). The employee empowerment itself stands as a form of authority or dominion diversion from the highest level to the lower level of management in a form of the responsibility to make decisions. The employee empowerment has been introduced in some organizations to enhance the customer satisfaction, escalating competitive predominance and performance (Carless, 2004:405; Hamed, 2010:65). It has been defined as the development of self-efficacy concept where empowerment is an act in intention to enhance the self-efficacy of organization members by identifying their inabilities, then followed by the act of eliminating them through organizational practices (Conger \& Kanungo, 1988). Many studies concludes that employee empowerment has positive outcomes toward employee performance (Ahmad \&
Manzoor, 2017; Degago, 2014; Suryadewi, et al., 2014; Tetik, 2016; Yilmaz, 2015). The gap in this research is whether the employee empowerment in Indonesia's hotel industry impacting the employee's performance.

H1: Employee empowerment has positive impact toward the employee's performance in Indonesia's hotel industry.

\section{Hard Skill}

The other factor that has negative impact towards the employee's performance level in a company or organization is the discrepancy of the employee's knowledge and skills level, where the hard skills were more applauded in the company (Ibrahim, Boerhannoeddin, \& Bakare, 2017). Most companies are more prioritizing professional certification and training programs in technical skills which are hard skills, instead of human skills which are soft skills because the hard skills are more directly relevant towards the daily employees' activities. Some other researches states that the importance of hard skills could elevates the individual ability in reaching the broader vision and making relation with work partner (Baum, 2008). Hard skills is a part of skills series required in a job, it is defined as a technical aspect related skill to perform several tasks in a job (Rainsbury et al., 2002). Poisson-de Haro \& Turgut (2012) states that hard skills which consist of technical and conceptual skills are important to managers. Other studies that measure the influence of hard skills toward employee performance conclude that hard skills have significant positive impact toward employee performance (Rusady, 2016). Many different research results that states either the positive or negative impact of hard skills, are becoming the next base of hypothesis on this research.

$\mathrm{H} 2$ : Hard skill has positive impact toward the employee's performance in Indonesia's 
hotel industry.

\section{Soft Skill}

The term of soft skills identical with personal skill related to attitude and behavior (Gibbons \& Lange, 2000; Moss \& Tily, 1996). Soft skill is an important both intra and inter personal (sosioemosional) for personal development, social participation and the success at work (Kechagias, 2011). Soft skills include communication skill, the ability to work in team and adaptation skill. The interest on soft skills mostly focuses on communication dan its role in building the relationship with customers including in service industry (Nickson et al., 2005). Rekha (2014) states that soft skills is a term which mostly related to someone's intellectual intelligence and the prime part of their individual contribution to gain the success of an organization. Organizations those directly facing their customers, generally more successful if they train their staff to use their skills effectively (Matteson et al., 2016).

The study about the importance of soft skills in work environment finds that the gap of soft skills could cause the high unemployment statistic (Seetha, 2014). Other study states that work force with expert technical skills but lack of soft skills could coause the soft skills gap to emerge (Robles, 2012). Soft skills have an important role in determining the success performance of a company or organization. In the 4.0 revolution era, soft skills have becoming very important in the current work life, whereas based on the LinkedIn report with title: Future of Skills 2019, states that work force with good soft skills are still very much needed. The survey result indicates that $47 \%$ of the respondents answer that soft skills are required because they are unique human ability in the middle of automation. National Association of Collages and Employeers research states that generally the workforce user requires skills that comprises of $80 \%$ soft skills and $20 \%$ hard skills. The late research also indicates the positive impact of soft skills toward the employee performance (Homer, 2001; Ibrahim, Boerhannoeddin \& Bakare, 2017; Kantrowitz, 2005; Weber et al., 2009). The next question would be how big is the influence of soft skills in hotel industry. The other Hypothesis in this research states that

H3: Soft skills has impact toward the employee's performance in Indonesia's hotel industry.

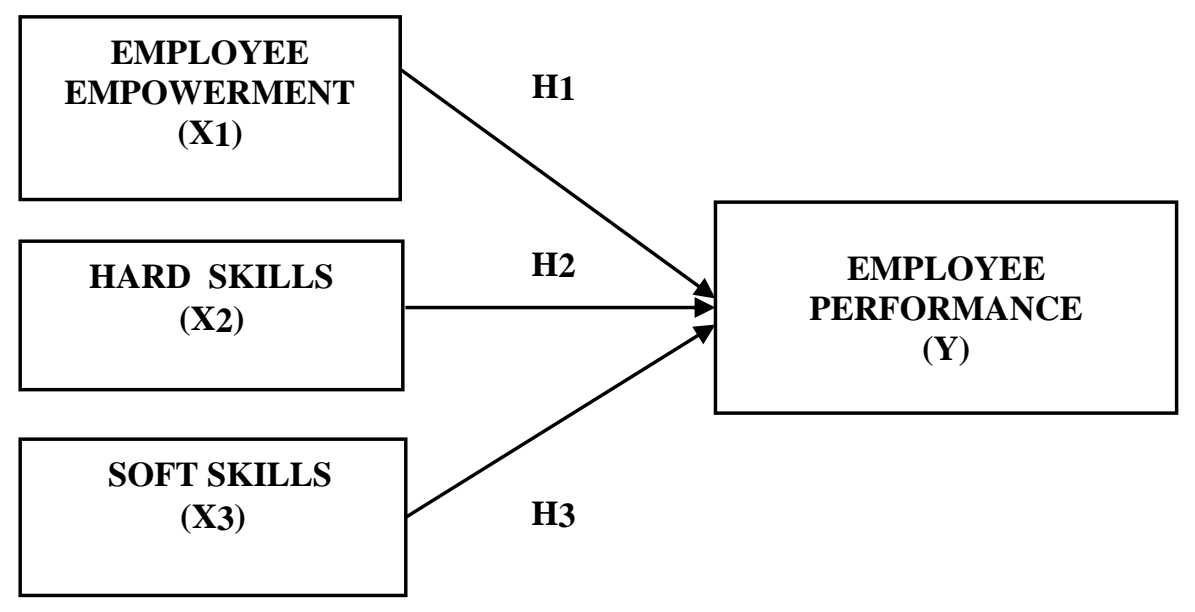

Figure 1. Research Model 


\section{RESEARCH METHODOLOGY}

The applied research methodology on this research is quantitative research with hypothesis test. The population used on this research is all the 4 star rated hotels in Indonesia, with 100 samples taken of those whom are still actively working at the premises. The instrument used was questionnaire developed from the former researches with related with variables of employee empowerment, soft skills and hard skills (Yilmaz, 2015; Hendarman \& Cantner, 2017; Koopmans et al., 2014). The digital questionnaire filling method was used and the samples taking was from January to March 2020 during the pandemic period. Structural Equation Modeling (covariance based SEM) were used to test the relation between the exogenous variable (independent) towards the endogenous variables (dependent). SEM is a multivariate technique that combines the analytic factor with regression which enables the researcher to measure both the variables and latent variables (either using the measurement theory approach or structural theory approach) altogether (Hair et al., 2014).

\section{RESULT}

In line with the purpose of the research which is to test the influence of employee empowerment, hard skill and soft skill towards the employee performance, then the structural equation modeling was used. Structural equation modeling has two forming models, those are measurement model and structural model. The measurement model defines the variance proportions of each manifest variables (indicator) which can be explained through the latent variable.

\section{Measurement Model Evaluation}

Measurement model is a model that connects the latent variables with manifest variables. Through the measurement model, it would be determind which indicator is more dominant in reflecting latent variable. According to Hair et al, (2014:605) if the manifest variables has factor loading value less then 0,50 then the corresponding variable is advised to be removed from model. There are 4 latent variables and 38 manifest variables on this research. The employee empowerment latent variable consist of $\mathrm{t} 12$ manifest variables, the hard skill latent variable consist of 8 manifest variables, the soft skill latent variable consist of 8 manifest variables and the employee Performance latent variable consist of 10 manifest variables.

Using the Robust maximum likelihood estimating method, the employee empowermentt, hard skill and soft skill influence towards the employee performance full model lines were obtained as presented on picture 2: 


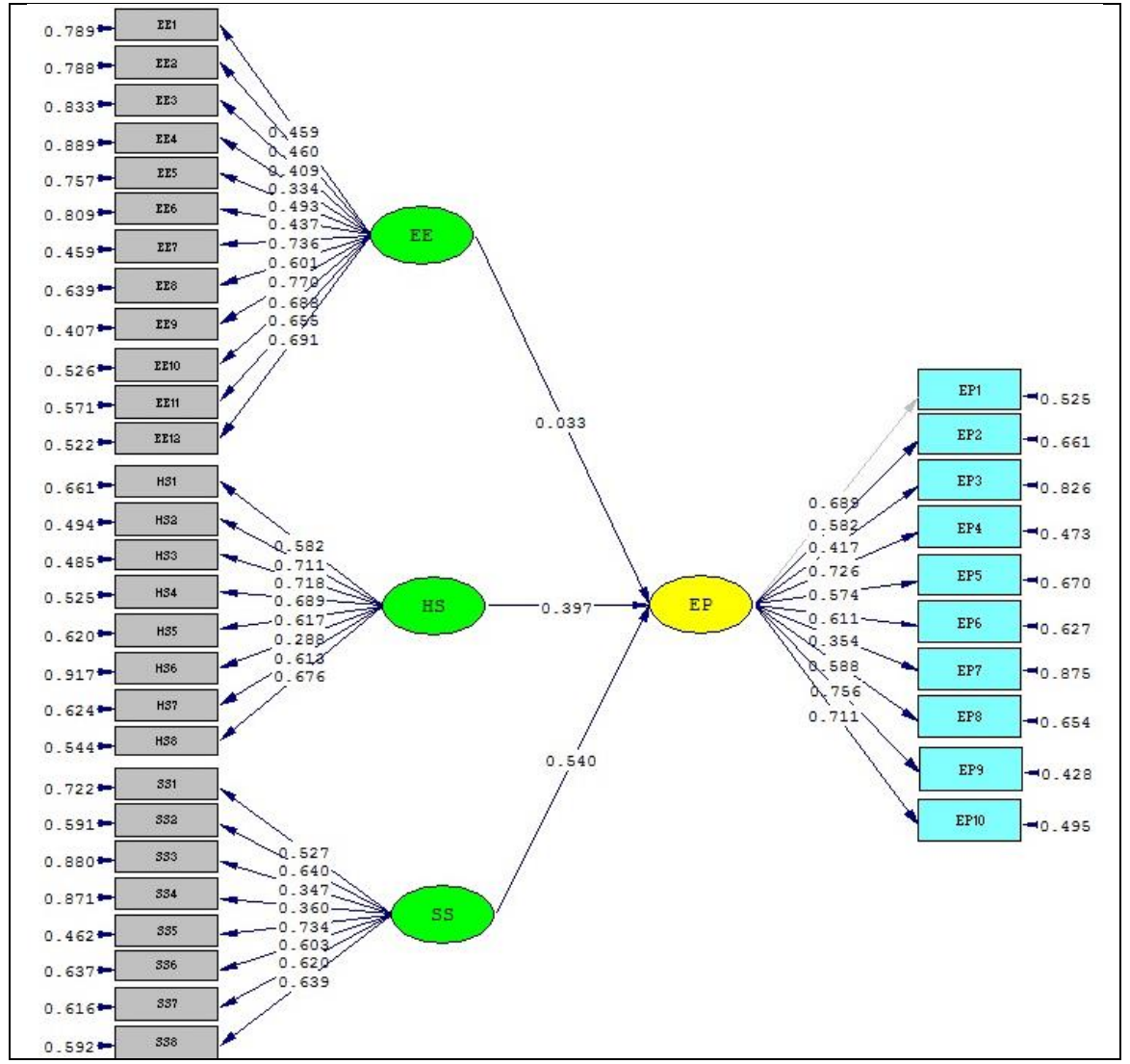

Figure 2. Preliminary Standard Coefficient Full Model

Through the loading factor shown on picture 1 , it can seen that there are 6 indicators of employee empowerment (EM) latent variable with smaller then 0,5 loading factor which are $\mathrm{EM}_{1}$ to $\mathrm{EM}_{6}$. In hard skill (HS) latent variable there is 1 indicator with loading factor less than 0,5 which is $\mathrm{HS}_{6}$, in soft skill (SS) latent variable there are 2 indicators with loading fator less than 0,5 which $\mathrm{SS}_{3}$ and $\mathrm{SS}_{4}$. Lastly in employee performance (EP) latent variable there are 2 indicators with loading factor smaller than 0,5 which are $\mathrm{EP}_{3}$ and $\mathrm{EP}_{7}$.

Furthermore, the indicators with loading factor less than 0,5 were removed from the model and the new estimation result is presented on picture 3 as follows: 


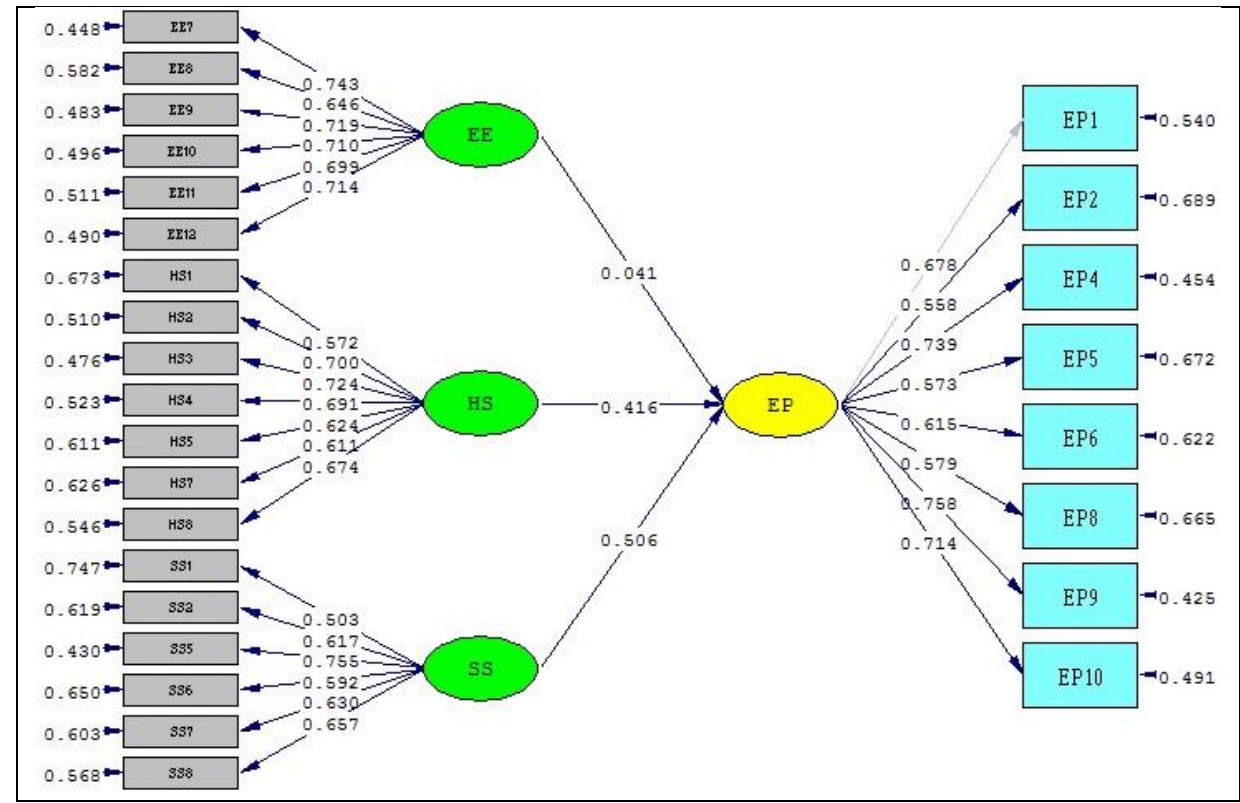

Figure 3. Final Standard Coefficient Model

As shown in picture 3, all the remaining indicators have loading factor more than 0,5 and stated to be valid to measure each of the latent variables. Furthermore, to find out whether the indicators used to measure the latent variables have the high validity degrees, then the construct reliability and variance extracted calculations were performed. Here are the calculation result of construct reliability and variance extracted for each latent

Table 1. Construct Reliability (CR) and Average Variance Extracted (AVE) of Each Latent Variable

\begin{tabular}{ccccc}
\hline Indicator & \multicolumn{4}{c}{} \\
\cline { 2 - 5 } $\mathbf{1}$ & $\mathbf{E E}$ & $\mathbf{H S}$ & $\mathbf{S S}$ & $\mathbf{E P}$ \\
$\mathbf{2}$ & - & 0,572 & 0,503 & 0,678 \\
$\mathbf{3}$ & - & 0,700 & 0,617 & 0,558 \\
$\mathbf{4}$ & - & 0,724 & - & - \\
$\mathbf{5}$ & - & 0,691 & - & 0,739 \\
$\mathbf{6}$ & - & 0,624 & 0,755 & 0,573 \\
$\mathbf{7}$ & - & - & 0,592 & 0,615 \\
$\mathbf{8}$ & 0,743 & 0,611 & 0,630 & - \\
$\mathbf{9}$ & 0,646 & 0,674 & 0,657 & 0,579 \\
$\mathbf{1 0}$ & 0,719 & - & - & 0,758 \\
$\mathbf{1 1}$ & 0,710 & - & - & 0,714 \\
$\mathbf{1 2}$ & 0,699 & - & - & - \\
$\mathbf{C R}$ & 0,714 & - & - & - \\
$\mathbf{A V E}$ & $\mathbf{0 , 8 5 6}$ & $\mathbf{0 , 8 4 2}$ & $\mathbf{0 , 7 9 6}$ & $\mathbf{0 , 8 5 6}$ \\
& $\mathbf{0 , 4 9 8}$ & $\mathbf{0 , 4 3 4}$ & $\mathbf{0 , 3 9 7}$ & $\mathbf{0 , 4 3 0}$ \\
\hline
\end{tabular}


According to Hair et al, (2014:605) the satisfying considered composite reliability (CR) is bigger than 0,70 . On employee empowerment latent variable, the average variance extracted value of 0,498 shows that averagely $49,8 \%$ of the information excisted in each indicator can be represented through the employee empowerment latent variable. Further more, the construct reliability value of employee empowerment latent variable $(0,856)$ is still bigger than the recommended value of 0,70 . In hard skill latent variable, the average variance extracted value of 0,434 shows that averagely $43,4 \%$ of the information excisted in each each indicator can be represented through the hard skill latent variable. Further more, the construct reliability value of hard skill latent variable $(0,842)$ is higher than recommended value of 0,70 .

In soft skill latent variable, the average variance extracted value of 0,397 shows that averagely $39,7 \%$ of the information excisted in each each indicator can be represented through the soft skill latent variable. Further more, the construct reliability value of soft skill latent variable $(0,796$ is higher than recommended value of 0,70 .

Lastly, in employee performance latent variable, the average variance extracted value of 0,430 shows that averagely $43,0 \%$ of the information excisted in each each indicator can be represented through the employee performance latent variable. Further more, the construct reliability reliability value of employee performance latent variable $(0,856)$ is higher than recommended value of 0,70 .

\section{Goodness of Fit Test}

Goodness of Fit test were performed to finds out whether the obtained model appropriately picturing the interelation of the studied variables so that it can be categorized as the appropiately fit model. (Hair et. al, 2014:576). The goodness of fit test in structural equation modelling can be seen based on the criterias shown below

Table 2. Goodness of Fit Result

\begin{tabular}{l|l|l}
\hline Goodness of Fit Measurment & Estimated Result Value & Note \\
\hline Chi-Square & $494,59 \quad(\mathrm{p}$-value 0,000) & Not Fit \\
\hline RMSEA & $0,075^{*}$ & Fit \\
\hline RMR & $0,039^{*}$ & Fit \\
\hline GFI & 0,683 & Not Fit \\
\hline NFI & 0,852 & Not Fit \\
\hline NNFI/TLI & $0,935^{*}$ & Fit \\
\hline IFI & $0,942^{*}$ & Fit \\
\hline CFI & $0,951^{*}$ & Fit \\
\hline
\end{tabular}

*fulfills the good model criteria

The test result using the $\chi^{2}$ (chisquare) formula, the value of 494,59 were obtained with p-value 0,000 . According to Hair et al, (2014:577) in sturctural equation modeling the p-value less than 0,05 is not favorable. As presented above, the smaller than $0,05 \mathrm{p}$-value shows that $\chi^{2}$ test is significant. Referring to the $\chi^{2}$ test then it is concluded that the obtained model has not fullfilling the overall good criteria model. But still according to Hair et al, (2014:578), as it is pretty difficult to 
obtain p-value higher than 0,05 on chi square test then, some other model goodness fit test were developed.

The other measurement method that still have connection with uji $\chi^{2}$ test is Root Mean Square Error of Approximation (RMSEA). The appropriate value of RMSEA was actually still being debated but according to Hair et al, (2014:579) if the RMSEA value is lower than 0,08 then the model can be accepted. On table 4.4 it can be seen that the RMSEA value of 0,075 is lower than 0,08 so that referring to the RMSEA value reference, the model considered to be appropriate. It is also can be seen the value of Incremental Fit Index (IFI), Tucker-Lewis Index (TLI) and Comparative Fit Index (NFI) all are bigger then 0,9 and fullfilling the appropriate model criteria. The goodness of fit test result shows that the obtained model fulfilling the criteria of goodness of fit on the scale of RMSEA \& RMR $(<0,08)$, and then IFI, TLI and CFI $(>0,90)$ so that in can be concluded that the result of model estimation can be accepted, or in other words the obtained empirical model is aligned with theoretical model.

\section{Structural Model Evaluation}

After the measurement of each latent variable has been determined then it will be desribed the structural model used to study the influence of exogenous latent variable towards the endogenous latent variable. Based on the result of data processing, the structural equation obtained would be tested as presented on the following table.

Table 3. Employee Performance Structural Model

\begin{tabular}{ccccc}
\hline Endegenous & \multicolumn{3}{c}{ Exogenous Constructs } & \multirow{2}{*}{ R-square } \\
\cline { 2 - 4 } Constructs & EE & HS & SS & \\
\hline EP & $\mathbf{0 , 0 4 1}$ & $\mathbf{0 , 4 1 6}$ & $\mathbf{0 , 5 0 6}$ & $\mathbf{0 , 7 3 2}$ \\
& $(\mathbf{0 , 5 1 9 )}$ & $(\mathbf{1 , 9 8 0 )}$ & $(2,417)$ & \\
\hline
\end{tabular}

Keterangan: Angka dalam kurung adalah nilai t-statistic.

Through the R-square value it was found that employee empowerment, hard skill and soft skill provides $73,2 \%$ of influence towards employee performance.

\section{Research Result Hypothesis Test}

\section{Hypothesis 1: Employee Empowerment Influence Towards Employee Performance}

\begin{tabular}{rlr}
$\mathrm{H}_{0}: \gamma_{1.1} \leq 0$ & \multicolumn{2}{l}{ Employee empowerment } \\
& has no positive influence \\
& towards & employee \\
Ha $: \gamma_{1.1}>0$ & Eerformance. \\
& Employee empowerment \\
& has positif influence \\
& towards & employee \\
& performance.
\end{tabular}

Based on the data presented in table 3 it can be seen that the $t_{\text {statistic }}$ value of employee empowerment variable towards employee performance $(0,519)$ and smaller then $t_{\text {kritis }}(1,64)$. Because of the $t_{\text {statistic }}$ is smaller than $t_{\text {kritis, }}$, then on the error margin of $5 \%$ it was decided to accept Ho while Ha was denied. So that based on the test result, it can be concluded that employee empowerment has no influence toward employee performance in Indonesia's hotel industry.

\section{Hypothesis 2: Hard Skill Influence Towards Employee Performance}
$\mathrm{H}_{0}: \gamma_{1.2} \leq 0 \quad$ Hard skill has no positive influence towards employee performance.


Ha $: \gamma_{1.2}>0$ Hard skill has positive influence towards employee performance.

Based on the data presented at table 3 it can be seen that $t_{\text {statistic }}$ value of hard skill variable towards employee performance $(1,980)$ and bigger than $t_{\text {kritis }}$ $(1,64)$. Because of $t_{\text {statistic }}$ value is bigger than $\mathrm{t}_{\text {kritis, }}$ so that with $5 \%$ of error margin then it is decided to deny Ho so that Ha accepted. So that based on the test result, it can be concluded that hard skill has positive influence toward employee performance in Indonesia's hotel industry.This study provides empirical proof that better hard skill supporting higher employee performance.

\section{Hypothesis 3: Soft Skill Influence} Towards Employee Performance

\section{$\mathrm{H}_{0}: \gamma_{1.3} \leq 0$ Soft skill has no positive influence towards employee performance. \\ Ha $: \gamma_{1.3}>0$ Soft skill has positive influence towards employee performance.}

Based on the data presented at table 3 it can be seen that $t_{\text {statistic }}$ of soft skill variable variable towards employee performance $(2,417)$ and bigger than $t_{\text {kritis }}$ $(1,64)$. Because of the $t_{\text {statistic }}$ value is bigger than $t_{\text {kritis, }}$, then on the error margin of $5 \%$ it was decided to deny Ho so that $\mathrm{Ha}$ accepted. So that based on the test result, it can be concluded that soft skill has positive influence toward employee performance in Indonesia's hotel industry. This study provides empirical proof that better soft skill supporting higher employee performance.

\section{DISCUSSION}

Based on the result through some testing, the hypothesis 1 test proves that there is no influence of employee empowerment towards the employee performance in Indonesia's hotel industry, it means that Indonesia's hotel industry better be putting more attention in developing the employee's skills factor because through hypothesis 2 and 3 tests, it was proven that both the hard and soft skills has positive influence towards the employees in Indonesia hotel industry. In the middle of hotel industry growth and competitiveness, and in effort to survive, it is very necessary to enhance the employee's performance quality. The hard and soft skills factors should be prioritized instead of the employee empowerment factor.

\section{CONCLUSION}

This research result contributes to Indonesia's hotel industry especially during the Covid-19 pandemic. The research shows that the Employee Empowerment factor is not influencing the employee's performance while both the hard and soft skills positively influencing the employee performance in Indonesia's hotel industry. The suggestion for the for the next research is to be able to add more samples in the test and also to add more variables to be tested in the purpose of studying their influence towards the employee's performance in Indonesia's hotel industry.

\section{REFERENCES}

Ahmad, I., \& Manzoor, S.R. (2017). Effect of teamwork, employee empowerment and training on employee performance. International Journal of Academic Research in Business and Social Sciences, 7(11), 380-394.

Baum, T. (2008). Implications of hospitality and tourism labour markets for talent management strategies. International Journal of Contemporary Hospitality 
Management, 20(7).

Carless, S. (2004). Does psychological empowerment mediate the relationship between psychological climate and job satisfaction?. Journal of Business and Psychology. 18(4). 405-425.

Conger, J. A., \& Kanungo, R. N. (1988). The empowerment process: Integrating theory and practice. The Academy of Management Review, 13(3), 471-482.

Degago, E. (2014). A study on impact of psychological empowerment on employee performance in small and medium scale enterprise sectors. European Journal of Business and Management, 6(27), 60-72.

Gibbons, W. D. \& Lange, T. (2000). Developing core skills-lessons from Germany and Sweden. Education + Training, 42 (1) . pp. 24-32.

Gull, A., Akbar, S. \& Jan, Z. (2012). Role of capacity development, employee empowerment and promotion on employee retention in the banking sector of Pakistan. International Journal of Academic Research in Business and Social Sciences, 2(9), 284-300.

Hamed, S.S. (2010). Antecedents and consequences of employees empowerment. Management Review: An International Journal, 5(1), 6494.

Hartline, M. D., \& Ferrell, O. C. (1996). The management of customercontact service employees: An empirical investigation. Journal of Marketing, 60(4), p.52-70.

Hendarman, A. F., \& Cantner, U. (2017). Soft skills, hard skills, and individual innovativeness. Eurasian Business Review, $\quad 8(2), \quad 139-169$. https://doi.org/10.1007/s40821-01700766.

Homer, M. (2001). Skills and competency management. Industrial and Commercial Training, Vol. 33 No. 2
, pp. 59-62.

Ibrahim, R., Boerhannoeddin, A., \& Bakare, K. K. (2017). The effect of soft skills and training methodology on employee performance. European Journal of Training and Development, 41(4), 388-406. https://doi.org/10.1108/EJTD-082016-0066

Hair, J. F., Black, W. C., Babin, B. J., Anderson, R.E., Tatham, R.L. (2014).Multivariate Data Analysis. (7th ed.), Pearson Prentice Hall Education International.

Kantrowitz, T. M. (2005). Development and construct validation of a measure of soft skills performance (Dissertation). Georgia Institute of Technology, Atlanta, GA.

Kechagias, K. (2011). Teaching and assessing soft skills. Thessaloniki (Neapolis): 1st Second Chance School of Thessaloniki, as part of the Measuring and Assessing Soft Skills (MASS) Project.

Koopmans, L., Bernaards, C., Hildebrandt, V., Van Buuren, S., Van Der Beek, A., J., \& de Vet, H. C. W. (2014). Development of an individual work performance questionnaire. International Journal of Productivity and Performance Management. 62(2), 6-28. Retrieved from https://doi.org/10.1108/1741040131 1285273.

Lytras, P.O.(2008). Competencies and human resource management: implications for organizational competitive advantage. Journal of Knowledge Management, 12(6), 4855.

Matteson, M., Anderson, L., \& Boyden, C. (2016). Soft skills: A phrase in search of meaning. Libraries and the Academy, 16:1, p.(71-88).

Meyerson,G.,\& Dewettinck, B. (2012). Effect of Empowerment on Employees Performance. 2(July), 40-46.

Moss, P., \& Tilly, C. (1996). Soft skills and 
race: An investigation of black men's employment problems. Work and Occupations, 23(3), 252-276.

Nickson, D., Warhurst, C., \& Dutton, E. (2005). The importance of attitude and appearance in the service encounter in retail and hospitality. Managing Service Quality: An International Journal, 15(2), 195 208.

Plummer, M.G., Petri, P.A., \& Zhai, F. (2014). Assesing the Impact Of ASEAN Economic

Integration on Labour Markets. ILO AsiaPasific Working Paper Series.

Poisson-de Haro, S. \& Turgut, G. (2012). Expanded strategy simulations: Developing better managers. Journal of Management Development, 31(3), 209-220.

Pragiwani, M., Alexandri, M. B., \& Chandra, R. (2018). Analysis of employee empowerment and knowledge management on employee performance in improving employee performance in tourism sector. Journal 3(1), 73-79.

Rainsbury, E., Hodges, D. L., Burchell, N., \& Lay, M. C. (2002). Ranking workplace competencies: Student and graduate perceptions. AsiaPacific Journal of Cooperative

Education

Rekha, U. (2014). Soft skills required for library professionals. National Conference on Management of Libraries, pp. 341-345.

Robles, M. M. (2012). Executive perceptions of the top 10 soft skills needed in today's workplace. Business and Professional Communication Quarterly, 75(4), 453-465.

Rusady, F. B. (2016). Hubungan Hard Skills, Soft Skills, dan Pengalaman Kerja dengan Kinerja Karyawan (Studi Kasus pada Karyawan Perpustakaan Universitas Sanata Dharma), Skripsi. Yogyakarta.
Saleem, S. \& Amin, S. (2013). The impact of organizational support for career development and supervisory suppoert on employee performance: An emperical study from Pakistani Academic Sector. Europen Journal of Business and Management, 5(5), 194-207.

Seetha, N. (2014). Are soft skills important in the workplace?-A preliminary investigation in Malaysia. International Journal of Academic Research in Business and Social Sciences, 4(4), 44-56.

Singh, N., Hu, C. \& Roehl, W. (2007). Text mining a decade of progress in hospitality human resource management research: identifying emerging thematic development. International Journal of Hospitality Management, 26(131-147).

Sonnentag, S. (2000). Expertise at work: Experience and excellent performance. International Review of Industrial and Organisational Psychology, Wiley, Chichester, 223264.

Suryadewi, P. C., Dunia, I. K., \& Suharsono, N. (2014). pengaruh pemberdayaan karyawan terhadap kinerja karyawan pada PT. Bali Segara Nusantara. Jurnal Jurusan Pendidikan Ekonomi, 4(1), 1-11.

Tetik, N. (2016). The effects of psychological empowerment on job satisfaction and job performance of tourist guides. International Journal of Academic Research in Business and Social Sciences, 6(2), 221-239.

Weber, M. R., Finely, D. A., Crawford, A. \& Rivera, D. J. (2009). An exploratory study identifiying soft skills competencies in entry-level manager. Tourism and Hospitality Research, 9(4):353-361.

Yilmaz, O. (2015). Revisiting the impact of perceived empowerment on job performance: Results from front-line employees. Turizam, 19(1), 34-46. 